\title{
COMMUNICATION OF THE PRODUCTION TEAM AND VIDEO EDITOR DIVISION IN BPPT TV PROGRAM PRODUCTION
}

\author{
Arbi Christional Lokananta \\ Universitas Budi Luhur, Indonesia. \\ arbi.lokananta@budiluhur.ac.id
}

\begin{abstract}
The internet and technological developments are advancing rapidly. All institutions competing to make television including government agencies BPPT TV. Media convergence occurs and this makes researchers interested in seeing how group communication is carried out on BPPT TV in producing their programs. This paper find out the communication of the production team division and video editor in making the production of BPPT TV. The external system and the internal system of group communication they do. The research method used is a qualitative approach and descriptive qualitative method by collecting data obtained from direct observation (observation) and in-depth interviews with informants. Data obtained through library research and documentation from various media, both print and online. The results showed that three important elements in the George C. Homans group communication were all activities, interactions and feelings carried out by members of the Production Team and Video Editor in the production of BPPT TV. The element of activities that they do include group communication which is carried out from the pre, production to post-production stages. Nowadays the development of television is increasing rapidly.
\end{abstract}

Keywords: Group Communication, Production Team, Video Editor, BPPT TV

\section{INTRODUCTION}

The mass media consists of newspapers, magazines, radio broadcasts, television, films, computers and the internet (online media). ${ }^{1}$ However, at this time the mass communication media that is growing very rapidly is online media. With online media, information from anywhere in the world can be obtained. High speed in providing information, making online media widely used by the public at this time. Today, the internet is considered important and has a wide network, connecting the simplest personal computers to the most sophisticated super computers.

Services provided by the internet include e-mail, Netnews, Telnet, File Transfer Protocol (FTP) and the world wide web or www, where the most widely used are e-mail and the world wide web or www. ${ }^{2}$ Other developments of the internet are search and track engines, such as browsers and search engines. It has a multimedia hyperlink function, which helps its users to browse quickly and systematically. Users can also move between existing relationships, read, listen, and print as if they were in a library. Moreover, internet users can search for relevant information by filtering out large data sets. Jobs are sought, supported, where the recipient no longer accepts what is reported, but instead seeks out or sends relevant information.

The success of the program airing in the online media in the news segment in Indonesia is inseparable from the role of the team members involved in it. If the members of the online media team are able to increase the page views / impressions of the program created, their prestige as workers will automatically increase along with the success of the program. In addition, the response of the audience which can be pros and cons of the straight news and feature news programs, can be used as an indicator of the success of both types of programs.

Creativity is an important factor for the success of a program in online media. This is likened to the basic ingredients of a building, creativity also becomes the basis or foundation in the process of making a program. A close collaboration is needed to process the creativity itself so that it will ultimately produce videos produced by BPPT TV. In practice, what is meant by teamwork itself is when each individual in the relevant BPPT TV production team carries out their respective roles or responsibilities responsibly.

Individuals involved all members of the production ranging from video editors, creatives and producers to BPPT TV. Good communication is an absolute requirement for the success of the broadcast program to be achieved. In the end, the entire team produced a video program that was of interest in the midst of online media competition. Group communication and interpersonal communication involve two or more individuals who are physically close to those who deliver it and respond to messages both verbally non-verbally. ${ }^{3}$

\footnotetext{
${ }^{1}$ Ardianto, Elvinaro, “Komunikasi Massa, Suatu Pengantar, Edisi Revisi”, Simbiosa Rekatama Media (2014): hal. 149

2 Bungin, Burhan, "Penelitian Kualitatif”, Kencana (2008): hal. 135

${ }^{3}$ Dean C. Barnlund, Interpersonal Communication (Boston: Houghton Mifflin 1968): hal.8-10.
} 
Group communication in the production of BPPT TV video programs produced by BPPT TV on BPPT TV must be clear and well-conveyed in order to be carried out properly so that the main objective of shooting is made at the production meeting. In the end, all the teams produced broadcast programs that were able to compete by displaying their superior programs that could attract the interest of the audience so as to produce high page views / impressions.

The reason the researcher chose the video program produced by BPPT TV to be investigated is as explained earlier, BPPT TV was developed from a website and until now there is a television program. Researchers see the relationship between social ability (sociability) with the group communication process is something interesting. ${ }^{4}$ The communication used by an online media program team should be investigated as learning for other online media in making programs, starting from the role of communication in the program produced by BPPT TV at http://iptv.bppt.go.id which supports the results of the program interesting news, group communication in the production process, in the delivery of material or ideas as well as technical issues that will be delivered at a production meeting starting from pre-production, production, until the video editing stage, namely the completion stage or post-production that must be done with careful planning.

Most textbooks define roles as functions performed by members in groups. These functions include giving opinions, explaining other members' assessments, or various tasks and other behavioral processes. The most prominent approach to the role is taken by Bormann, who defines the role based on the expectations of the discussion participants. ${ }^{5}$ The maximization of group communication in the production of programs produced by BPPT TV can demonstrate practical operational optimization that can be done through approaches that can differ at any time depending on the situation and conditions so that the production goal of a broadcast program reaches an expected viewing. In this communication it is hoped that there is positive feedback between the individuals of each crew, to produce a positive level of performance. Differences of opinion that occur during discussions or meetings between group members on the production of programs produced by the production team on BPPT TV allow differences in opinions that members have before discussing opinions after discussion. Paulson draws conclusions about this, that the pressures to achieve a unity of opinion within the discussion group are quite strong and that "independent judgment" often has to succumb to these pressures. ${ }^{6}$ Thus, the success of pageview or viewers of a quality program video show produced by BPPT TV is the result of good group communication success. Each member gives positive feedback between individual crew when communicating in groups, in order to produce the level of performance as expected in the initial work plan that is the team's goal.

Researchers feel interested in taking this theme and researching it because they want to find out the group communication with the scope of performance in the process of making or producing a program so that it is successful in producing or producing quality shows with high pageview or viewers according to team expectations. The researcher wants to see how the group communication is carried out by the production team and video editors who use the internet platform in airing. Production in internet-based shows is different from what is shown on television. Technological progress is increasingly advanced so that researchers want to see how the group's communication process. ${ }^{7}$ Based on this thought, the researcher chose to explore and examine the performance involved in the production process, which was given the title: " COMMUNICATION OF THE PRODUCTION TEAM AND VIDEO EDITOR DIVISION IN BPPT TV PROGRAM PRODUCTION".

Based on the background of the problems outlined above, the Researcher proposes the following formulation: "What are the three elements contained in the group communication division of the Production Team and Video Editor in the production of the BPPT TV (TV Technology Assessment and Application Agency) program? How are the external and internal systems in the group communication division of the Production Team and Video Editor in the production of the BPPT TV (TV Technology Assessment and Application Agency) program?". The purpose of this study was to determine the three elements contained in the group communication communication division of the Production Team and Video Editor in the production of the BPPT TV program (Agency for Assessment and Application of TV Technology) as well as external and internal systems in group communication in program production in BPPT TV.

\section{METHODOLOGY}

Researchers use the postpositivism paradigm. The reason the researcher uses the Postpositivism paradigm is that facts are not free but are loaded with theory, none of the theories can be fully explained with empirical evidence, empirical evidence has the possibility to show anomalous facts, facts are not free but full of

\footnotetext{
${ }^{4}$ Louis Lerea dan Alvin Goldberg, "The Effects of Socialization Upon Group Behaviour," Speech Monographs 28 (1961): hal.60-64.

${ }^{5}$ Bormann, Discussion and Group Methods, hal.197.

${ }^{6}$ Stanley F. Paulson, "Pressures Toward Comformity in Group Discussion," Quarterly Journal of Speech 44 (1958): hal.50-55.

7 Stanley F. Paulson, "Pressures Toward Comformity in Group Discussion," Quarterly Journal of Speech 44 (1958): hal.50-55.
} 
the value of interaction between subjects and objects of research and results research is not objective reportage but the result of human interaction and a universe that is full of problems and is constantly changing. ${ }^{8}$

Postpositivism approach to communication can be seen from the Postpositivism perspective as follows: bring a great influence on social sciences including communication science, Postpositivism perspective sees the community not as an object that when examined only presents the same effect, humans are alive and can construct certain responses when examined, objectivity cannot be found as we find it when things. Nevertheless, according to Postpositivism, objectivity can be found as far as its relationship with the theory it uses.

Researchers use the Postpositivism paradigm, to find out the communication between the Production Team and Video Editor in producing programs on BPPT TV, because this Postpositivism paradigm, the abstract about communication developed must be tested through observation of communicative actions. So the researcher wants to see the communication between the Production Team and Video Editor in producing the program on BPPT TV and the researcher is writing in written form. The qualitative approach aims to get a general understanding of social reality from the perspective of the participant. This understanding was not determined in advance but was obtained by the researcher after conducting an analysis of the social reality that was the focus of the study and then a conclusion was drawn in the form of general understandings of the facts that occur in the communication process of the Production Team and Video Editor in producing programs on BPPT TV .

The researcher considers the qualitative approach in accordance with the title of this qualitative research because qualitative research is subjective research. Qualitative research aims to explain the phenomenon profusely. This research does not prioritize population size or sampling. If the data collected is deep and can explain the phenomenon examined carefully, there is no need to look for other sampling. ${ }^{9}$ Here what is more important is the depth of data quality not the quantity of data. Researchers will examine the widest possible so that this study is more in-depth and not based on statistical figures.

Qualitative research is not always necessary to examine all the news in the population, which is important in qualitative research check the reliability, namely how the power of data reflects the authenticity and simplicity of each information. Whereas checking the validity is related to the initial evaluation of research activities in the field that is full of attention to the research situation (such as place, time, and preparation of informants who want to meet), research problems and data that will be used by researchers. ${ }^{10}$

The researcher used the appropriate research method to find out the communication role of the Production Team and Video Editor groups in producing programs on BPPT TV, which was a descriptive qualitative research method which was explorative in nature. So, in carrying out research, researchers understand the phenomenon in broad outline without ignoring the possibility of certain focus choices specifically. ${ }^{11}$

\section{RESULT AND CONCLUSION}

The organizational structure used by BPPT is a functional organizational structure in which the leader can order to any employee whose position is lower level below him, and a subordinate can face him directly according to his responsibilities and functions. In a world of technology BPPT also requires mass media and broadcast media, therefore BPPT makes BPPT TV on BPPT TV, there are also several divisions, namely:

\footnotetext{
${ }^{8}$ Ardianto, Elvinaro, Filsafat Ilmu Komunikasi, Simbiosa Rekatama Media, Bandung, 2007, hal. 100

${ }^{9}$ Rachmat Kriyantono, Teknis Praktis Riset Komunikasi, Kencana Prenada Media Group, Jakarta, 2007 , hal. 58

${ }^{10}$ Denzin Guba, Teori Paradigma Penelitian Sosial, Penerjemah Agus Salim, 2003, Hal. 59

${ }^{11}$ Ghony, M. Djunaidi, Metodelogi Penelitian Kualitatif, Ar-ruzz Media, Jogjakarta,2012: Hal: 29
} 


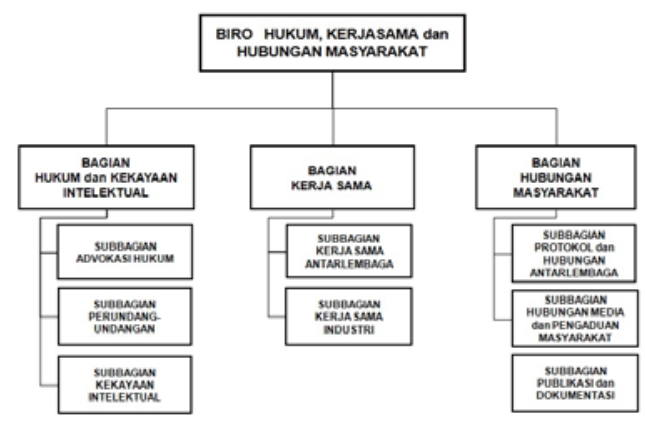

Pic 2.1

PICTURE OF ORGANIZATIONAL STRUCTURE OF BPPT TV

Source : (www.bppt.go.id/layanan-informasi-publik/2828-bppt-tv-s2e05-bppt-360-update-berita-sepekan diakses pada Januari 2019)

\section{Production of BPPT TV}

\section{A. Pre-Production}

Pre production is the earliest stage in producing a program. The initial stage before making TV production at BPPT TV at that time was a producer who held the production of BPPT TV, namely Septa giving the task to the production team to find out what equipment should be used when before the production took place on this BPPT TV. So that the event can run smoothly without any obstacles. Crew calls are made to determine who is on duty. Cameraman, creative team, production team and other video editor team are determined by who is chosen to do the shooting process.

\section{B. Production}

The next step from the pre-production stage is the production stage. In this stage the BPPT TV production team will begin to carry out the planned arrangements in the previous stage. Before carrying out production activities each person prepares equipment and things needed during the production process. The Cameraman team prepares cameras, audio and other equipment. And prepare everything needed so that the shooting process can run smoothly and according to plan.

The BPPT TV production process is carried out in a studio located in the Tangerang area. The BPPT TV production team departed for the designated location. The trip to the shooting location takes approximately four hours. Starting from the selection of positions that will be used as a place for interviews, lighting, camera settings and KASUBAG Mass Media and Public Complaints patiently direct the shooting process. In this process Septa directs that the shooting process runs smoothly and looks neat so that during post-production will facilitate the video editor in the video editing process.

\section{Post-Production}

Post Production is the most recent stage in producing a program, in this stage the video editor has the duty to compile the video so that it becomes a unified whole so it is worth watching. In this stage the creative team and the producer work together after producing. In short, after everything is in line and meets the criteria desired by the producer, the unified video is watched and re-examined by the producer. After KASUBAG Media Press and Public Complaints agreed then, it was checked on audio. After all the processes have been completed, then it is submitted to Septa to upload according to a predetermined schedule.

A video editor must also be familiar with camera angles and program concepts. Can distinguish talk show programs and interviews. Because there is a difference in the selection of images and artistic touches. If the talk show program will really need clear pictures from the source, while direct interviews are more on natural images. Video editors are responsible for the images they specify. Video editors must know the meaning, purpose and image information, so that people watching can understand the results of the images displayed on BPPT TV.

The Video Editor Team is the person who is responsible for cutting images or videos and video results from tapes and memory cards. An editor must have a "sense of art" because in work there is a creative element of accuracy, accuracy, and patience. A video editor must pay attention to the goals and interests of the program that is done by video editing techniques, by paying attention to the elements, motion, words, rhythm and artistic aspects. Not only following the story line but arranging the unity of information, elements of art by paying attention to the beauty and motivation of each picture. A video editor is forever working at the end of a program (post-production) but can also work before the program airs, for example live and delay programs. A video editor 
will prepare the material to be displayed in the form of VT (Video Tape) or Footage, which is a set of footage from a recording that is rearranged with additional narration to broadcast. Post Production is the most recent stage in producing a program, in this stage a video editor whose job is to compile the video to become a unified whole so it is worth watching.

\section{Three Elements in Group Communication Production Team Division and Video Editor in BPPT TV Program Production}

The theory of group communication of external systems and internal systems of George C. Homans states that in group communication there are three important elements namely, activities, interactions, and feelings. These three elements that lead to formal group assignments are called external systems. Activities are all forms of actions that each group member takes.

Then the results of the researcher's interview are associated with the theory of External Systems Group Communication and George C. Homans' Internal Systems, the process of activities carried out on group communication in the production of the BPPT TV Program each has an equally important and interrelated role between with one another in achieving common goals. This includes all forms of actions related to their job responsibilities. What's more initially BPPT did not have television channels. Then later as time goes by and developments in the camera world and in the internet world they produce full video products namely BPPT TV which can be accessed via apps, Youtube, or the website iptv.bppt.go.id/news/ This requires more communication with each - each member. In addition to the many technical adjustments made, they also made adjustments to their individual framing or understanding. Because of the very drastic difference from still photos, it is now a video production with audio. However, they have succeeded in the transition process and the group's communication process because it is proven that they are now not only working on regular video news projects such as BPPT 360 and BPPT Live. This certainly requires a lot of group communication within the team to adjust work within the team.

Group communication is a face-to-face interaction between three or more people, with known goals, such as sharing information, protecting themselves, solving problems and having a specific work plan arrangement to achieve group goals. In the BPPT TV Program group communication is carried out by the Producer, Creative, and Video Editor through several stages of activity. First, in the production of regular video news, each member of the Producer, Creative, and Video Editor in the production of the BPPT TV Program will convey the idea or concept of the video theme to be appointed shooting. This depends on mutual agreement on the momentum and content of the theme to be raised. After being determined together with consultation with the Producer, a new consultation will be held between the Creative, about the concept of place, and the contents of the script or storyline. Then the results of their communication are conveyed to the team such as location problems and the need for tools that might be needed. The last stage of the group communication activity is to submit the work plan to the Video Editor to determine what video and audio will be taken later to avoid miscommunication between the crew in charge with the crew in the office, in this case the Video Editor will do the video finishing and audio of the shooting. The division of the team is then carried out before starting production, what kind of video concept is delivered, what kind of shooting concept will be delivered, when will the work plan be submitted and about the venue also delivered.

Secondly, the production of the BPPT TV Program, both BPPT 360 or BPPT Live, requires tools. The need for shooting equipment such as cameras needed by the production team will communicate with the Creative and Producer. Likewise the audio tools needed will communicate with each other team. The lighting tools that were needed by the team also discussed with the Creative and Producers. While the Video Editor will be invited to discuss and be asked for opinions on what kind of video is expected so that it determines what technical tools are needed by the team in the production of the BPPT TV.

The second element is interaction. Interaction is the process of interacting small groups in the production of the BPPT TV Program. George C. Homans emphasizes interpersonal communication within the group members themselves. So each member in this group shows mutual dependence and respond to each other in behavior. The BPPT TV has a number of members of the production team. Some are close only at the time of the production process, some are interacting more. Each of them has more closeness between several other group members. Interaction they do when they feel comfortable, will be very intense outside of work hours. For example, to the cafeteria together or to camping together. This is due to the interaction in the production of the BPPT TV Program, so that outside of work they need each other for example to talk about their personal lives.

The third element is feeling. The feeling that George C. Homans means is the same as Heider's concept of likes and dislikes which consists of negative and positive feelings felt by group members towards other members. George C. Homans relates this to the intrapersonal communication within each of them. So each member in the BPPT TV Program production group has different feelings about each other about fellow group members. However, despite that each member who has different feelings towards fellow members remains a professional to carry out the communication task itself. A Producer, Creative, and Vidoe Editor 
remain in their respective functions, communicating well in the production of the BPPT TV.

One of the Production Producers of the BPPT TV Program who has positive feelings and positive feelings in communicating groups with other members of the team but there are those who feel uncomfortable communicating with other members of the team. For example, one producer of the BPPT TV Program, the other, felt that members in the team sometimes made bad moods so that they were distracted in their work. However, there are also those who are comfortable communicating with other team members such as Creative or Video Editor. Then there are also those who are comfortable with Video Editor and others who feel they don't like it. Other members' uncomfortable feelings are caused by differences in framing so chatting becomes a preference in choosing interlocutors who both have the same frame. This happens because of differences in information held, so that arises such uncomfortable feelings. There are Video Editor likes and there are those who are less comfortable interacting with it. Feelings that are owned by them more or less affect their interaction with each other. If they like or are comfortable with group members in the BPPT TV Program, then they will interact more intensely. Conversely, if they dislike or are uncomfortable with group members in the BPPT TV Program they will keep their distance in the sense of not leaving their professionalism but merely interacting in terms of work.

\section{Group Communication System Division of Production Team and Video Editor in Production of BPPT TV}

\section{A. External Communication System Division of Production Team and Video Editor Division in Production BPPT TV}

Group Communication Theory according to George C. Homans said the External System is the result of the process of forming activities, interactions and feelings directed at formal tasks or responsibilities of their work in a group. This is also called the formal system of group communication and is also called the task of communication.

This is evident from the results of interviews conducted by Har as the Producer, it can be seen that the external system as a Producer is that he communicates in groups with the Creative, with the Video Editor or with other teams in the production of the BPPT TV through several stages. If, he wants to talk about BPPT 360 or BPPT Live then he has a meeting beforehand. Each of them explained beforehand about the work plan they have. What kind of video is requested, how long it is, what angle to expect, how many videos are made and when the video should be shown. After that, Har will convey the information he has from the meeting results to other team members such as Creative and Video Editor. Then the Producer who conveys everything that has to do with the shooting to Creative and Video Editor. Vice versa if Creative and Video Editor want to convey something about shooting then they can convey it directly to the Producer. Then regarding the regular video news production, communication is usually done directly face to face or via messenger like Whatsapp without having a scheduled meeting. If there is something very important, sometimes a meeting is scheduled so that it can communicate in the team. So in the team there is no communication hierarchy that is sacred to obey. Each member has the right to convey aspirations or ideas to the team.

Group Communication Theory according to George C. Homans in connection with the External System is evident from the results of the researcher's interview with Sely as the Creative BPPT TV Program, it can be seen that the external system as Creative is that he communicates groups with the Producer and Video Editor through several stages. He conveyed the concept of the video idea that shooting was intended to be a regular video news project of the BPPT TV Program to the Producer, if it was agreed upon, the Producer would submit it to the Video Editor and other teams. And do not rule out the possibility if there is input on other video projects BPPT TV Program, he can also convey it to the Producer, if it has been agreed upon, the Producer will deliver it to the Video Editor and to other teams. Then regarding matters relating to technical matters, a Producer can convey obstacles or needs for shooting to the team. So as not to occur missed during shooting.

Group Communication Theory according to George C. Homans in connection with the External System is evident from the results of the researcher's interview with the Video Editor of the production of the BPPT TV Program, Septa. Be creative through several stages. The external system can be divided into two production models. The one that is regular news, this kind of production is usually communication activities more to daily communication, relax, while talking with people. One team can both look for ideas and review together. In the end it can produce blueprints, become scenarios or storylines. The difference with production that is promotional BPPT TV, communication is more often communicate with third parties. This is more formal in nature and there are regular meetings that are prepared and planned. From the meeting, drafted work references ranging from research to budgeting to how the production shows. Then when the production period is like this the Video Editor communication will more often receive updates by Whatsapp groups or chat groups on mobile. So that the Video Editor immediately knows about what is needed or what changes have taken place in the field. Then later 
when entering postproduction (production) the communication is more direct, more informal, not too formal. Then Video Editor often chats with Producers, who already know the storyline, already know the production flow. That's intense every day every time when the postproduction (production) runs. Since when the team was looking for planning for coverage in routine monthly activities or questionnaires. When searching for new ideas then applied in a draft until finally the project is final, during the process also the communication is carried out. The flow of interaction is basically not arranged like a tree, there are those above and below. In the end in one team, everything is equal when practicing communication. When the communication process takes place the position is only as a differentiator jobdesk. For Video Editor communication between groups that occur, helping him design, arrange work plans, what should be done with the video results of shooting. When you have to do the video editing process, when you have to postproduction (production), the communication is done. The external system carried out in the team eventually face to face communication became routine, natural, and usual.

\section{B. Internal Communication System Division of Production Team and Video Editor Division in BPPT TV}

George C. Homans states the internal system grows due to the system external. However, both grow simultaneously. This internal system is the result of the influence of interactions on feelings because according to George C. Homans various kinds of activities often cause complexity. Thus, an internal system is the likes and dislikes that group members have towards fellow group members beyond what is needed by their group assignments or job responsibilities so as to produce a new set of activities that are not directly related to their formal group task responsibilities. This is called the informal system part of a group (internal system).

The results of an external system that forms a new set of activities and interactions (internal system) group communication in the production of the BPPT TV is the result of the influence of interactions on feelings is as follows. According to him it is natural that an internal system is formed because each has different competencies, causing framing. 